Edunomika - Vol. 01, No. 02 (Agustus 2017)

\title{
PENINGKATAN KEMAMPUAN MENULIS TEKS RECOUNT MELALUI METODE ESTAFET WRITING PADA SISWA KELAS IX A SMP NEGERI 6 SUKOHARJO SEMESTER I TAHUN PELAJARAN 2016/2017
}

\author{
Sri Lahir \\ SMP Negeri 6 Sukoharjo, Jawa Tengah \\ Email: srilahir@gmail.com
}

\begin{abstract}
Abstrak: Penelitian ini bertujuan untuk meningkatkan kemampuan menulis teks recount pada siswa kelas IX A SMP Negeri 6 Sukoharjo semester I Tahun Pelajaran 2016/2017 melalui metode estafet writing. Penelitian ini menggunakan bentuk penelitian tindakan kelas yang dilaksanakan dalam 2 (dua) siklus, dilaksanakan di SMP Negeri 6 Sukoharjo dengan subjek penelitian seluruh siswa kelas IX A SMP Negeri 6 Sukoharjo semester I Tahun Pelajaran 2016/2017 yang berjumlah 22 siswa. Metode penelitian menggunakan Penelitian Tindakan Kelas. Pengumpulan data dilakukan melalui observasi, dokumentasi dan tes. Analisis data dilakukan dengan 3 (tiga) tahapan meliputi: reduksi data, penyajian data dan penarikan kesimpulan atau verifikasi. Hipotesis menyatakan diduga melalui metode estafet writing dapat meningkatkan kemampuan menulis teks recount pada siswa kelas IX A SMP Negeri 6 Sukoharjo semester I Tahun Pelajaran 2016/2017. Dari data empirik menyatakan melalui penerapan metode estafet writing dapat meningkatkan kemampuan menulis teks recount dari kondisi awal nilai rata-rata 70 dengan ketuntasan 54,54\% ke kondisi akhir pada siklus II nilai rata-rata 85 dengan ketuntasan 86, 36\% pada siswa kelas IX A SMP Negeri 6 Sukoharjo semester I Tahun Pelajaran 2016/2017. Sehingga dapat disimpulkan bahwa melalui metode estafet writing dapat meningkatkan kemampuan menulis teks recount pada siswa kelas IX A SMP Negeri 6 Sukoharjo semester I Tahun Pelajaran 2016/2017.
\end{abstract}

Kata Kunci: kemampuan belajar, Bahasa Indonesia, menulis teks recount, estafet writing

\begin{abstract}
This study aims to improve the ability to write recount text on the students of class IX A of Junior High School 6 Sukoharjo in the first semester of 2016/2017 through the method of writing relay. This research uses classroom action research conducted in 2 (two) cycles, conducted in SMP Negeri 6 Sukoharjo with research subject all students of class IX A Junior High School 6 Sukoharjo first semester of Student Year 2016/2017 which amounted to 22 students. Research method using Classroom Action Research. Data collection is done through observation, documentation and test. Data analysis was done with 3 (three) stages including: data reduction, data presentation and conclusion or verification. Hypothesis states allegedly through the method of writing relay can improve the ability to write text recount on the students of class IX A SMP Negeri 6 Sukoharjo first semester of the 2016/2017 Lesson Year. From the empirical data states through the application of the method of relay writing can improve the ability to write text recount from the initial condition of the average value of 70 with the completeness of $54.54 \%$ to the final condition in cycle II average value 85 with completeness 86, 36\% in students class IX A Junior High School 6 Sukoharjo first semester Lesson 2016/2017. So it can be concluded that through the method of writing relay can improve the ability to write text recount on the students of class IX A Junior High School 6 Sukoharjo first semester of the 2016/2017 Lesson Year.
\end{abstract}

Keywords: ability to learn, Indonesian, writing recount text, estafet writing 


\section{PENDAHULUAN}

Bangsa yang besar adalah bangsa yang memperhatikan aspek sumber daya manusia atau SDM sebagai aspek utama dalam meningkatkan dan mengembangkan suatu bangsa ke arah yang lebih baik, tetapi tanpa mengesampingkan aspek-aspek yang lain. Salah satu cara yang paling strategis dalam peningkatan sumber daya manusia tersebut tentunya melalui pendidikan. Karena pendidikan merupakan cara terbaik untuk meningkatkan kualitas sumber daya manusia suatu bangsa (Tho'in, 2017: 162). Dengan demikian, mau tidak mau jika bangsa Indonesia tidak mau tertinggal dengan negara-negara lain baik pemerintah maupun rakyatnya harus menyadari betul dengan serius pentingnya pendidikan bagi generasi anak bangsa.

Bangsa Indonesia sebenarnya salah satu bangsa yang memiliki ciri khas bahasa resmi negara yang unik yang sama dengan nama negaranya, yaitu Bahasa Indonesia. Bahasa Indonesia menjadi bahasa persatuan dari Negara Kesatuan Republik Indonesia (NKRI) yang terdiri dari berbagai suku, agama, ras, termasuk bahasa daerahnya. Di tengah-tengah perbedaan bahasa inilah Bahasa Indonesia hadir sebagai bahasa persatuan. Pelajaran Bahasa Indonesia sebagai salah satu mata pelajaran yang wajib diikuti oleh siswa di sekolah pada jenjang pendidikan dasar dan menengah dipandang sebagian siswa sebagai mata pelajaran yang sulit dan kurang diminati. Padahal siswa seharusnya menyadari bahwa kemampuan memahami pelajaran Bahasa Indonesia sangat dibutuhkan dalam menghadapi zaman yang semakin cepat, era persaingan global.

Cara belajar yang akan dialami oleh siswa sepenuhnya ditentukan oleh pertimbangan professional guru mengenai sifat, tujuan, materi, kemampuan awal siswa (entry behavior), sifat sumber materi dan suasana belajar. Jika seorang pendidik mampu menguasai dan menentukan metode belajar yang sesuai dengan kebutuhan siswa maka proses belajar mengajar di kelas akan berlangsung dengan baik. Hal tersebut juga akan berdampak baik terhadap prestasi belajar yang dicapai siswa (Djamarah, 2000:24). Dengan demikian peranan seorang pendidik (guru) dalam kegiatan belajar mengajar sangat penting, karena berhasil atau tidaknya kegiatan belajar mengajar tersebut sangat ditentukan oleh kreativitas guru dalam mengemas suatu mata pelajaran sehingga dapat menarik minat siswa untuk lebih mendalami dan mempelajari mata pelajaran tersebut.

Keberhasilan pembelajaran dipengaruhi oleh banyak faktor, diantaranya faktor minat, bakat, tingkat intelegensi, sikap, dan strategi pembelajaran. Pada pembelajaran Bahasa Indonesia, diperlukan strategi pembelajaran yang sesuai yang melibatkan siswa seoptimal mungkin baik secara intelektual maupun emosional. Oleh karena itu, guru dituntut untuk menguasai strategi-strategi penyampaian materi serta menguasai materi yang akan disampaikan.

Guru yang profesional akan selalu berupaya untuk meningkatkan pemahaman siswa terhadap materi yang diajarkan. Hal ini sejalan dengan tujuan pendidikan nasional yang dirinci sebagai berikut: 1) Mendidik adalah usaha sadar untuk meningkatkan dan menyiapkan peserta didik melalui kegiatan bimbingan, pengajaran dan atau latihan bagi perannya dimasa yang akan dating; 2) Peserta didik adalah anggota masyarakat yang berusaha mengembangkan din melalui proses pendidikan pada jalur dan jenjang pendidikan tertentu (Pribadi, 2009:42).

Dalam upaya meningkatkan proses belajar, guru harus berupaya menciptakan strategi yang cocok, sebab dalam proses belajar mengajar yang bermakna, keterlibatan siswa sangatlah penting, hal ini sesuai dengan pendapat Ilyas (2008: 12) yang menyebutkan bahwa kadar pembelajaran akan bermakna apabila: 1) Adanya keterlibatan siswa dalam proses belajar mengajar. 2) Adanya keterlibatan intelektual-emosional siswa baik melalui kegiatan menganalisa, berbuat dan pembentukan sikap. 3) Adanya keikutsertaan siswa secara kreatif dalam menciptakan situasi yang cocok untuk berlangsungnya proses belajar mengajar.

Keberhasilan dari suatu kegiatan sangat ditentukan oleh perencanaannya. Apabila perencanaan suatu kegiatan dirancang dengan baik, maka kegiatan akan lebih mudah dilaksanakan, terarah serta terkendali. Menurut Sagala (2008:6), perencanaan pembelajaran berperan sebagai 
acuan bagi guru untuk melaksanakan kegiatan pembelajaran agar lebih terarah dan berjalan efisien dan efektif. Dengan perkataan lain perencanaan pembelajaran berperan sebagai skenario proses pembelajaran. Oleh karena itu perencanaan pembelajaran hendaknya bersifat luwes (fleksibel) dan memberi kemungkinan bagi guru untuk menyesuaikannya dengan respon siswa dalam proses pembelajaran sesungguhnya.

Kegiatan mengajar merupakan upaya kegiatan menciptakan suasana yang mendorong inisiatif, motivasi dan tanggung jawab pada siswa untuk selalu menerapkan seluruh potensi diri dalam membangun gagasan melalui kegiatan belajar sepanjang hayat. Gagasan dan pengetahuan ini akan membentuk keterampilan, sikap dan perilaku sehari-hari sehingga siswa akan berkompeten dalam bidang yang dipelajarinya. Ada kalanya dalam memberikan materi pelajaran kepada anak didik tidak selalu berjalan lancar sesuai dengan perencanaan atau gagal. Banyak faktor yang menyebabkan kegagalan dalam memberikan materi pelajaran. Dari faktor anak, tingkat intelegensi dan latar belakang anak didik yang berbeda-beda menyebabkan hasil pembelajaran yang tidak sama pula. Sedangkan penyebab lain dari pihak guru adalah cara penyampaian materi yang dianggap anak didik sulit memahaminya, kurangnya media pembelajaran, metode pembejaran yang salah, sehingga tujuan pembelajaran kepada anak didik tidak mengenai sasaran, dan masih banyak lagi sebab-sebab kegagalan siswa untuk mencapai tujuan pendidikan.

Prestasi belajar Bahasa Indonesia materi kemampuan menulis teks recount pada siswa kelas IX A SMP Negeri 6 Sukoharjo Kecamatan Sukoharjo, Kabupaten Sukoharjo Semester I Tahun Pelajaran 2016/2017 termasuk rendah. Dari data prestasi belajar Bahasa Indonesia materi kemampuan menulis teks recount kelas IX A, nilai rata-rata prestasi belajar siswa adalah 70, di bawah nilai Kriteria Ketuntasan Minimal (KKM) yang ditetapkan untuk mata pelajaran Bahasa Indonesia yaitu 75 . Hanya 12 siswa $(54,54 \%)$ yang mencapai nilai KKM dari total 22 siswa kelas IX A. Sedangkan 10 siswa yang lain nilainya masih di bawah KKM. Hal ini menunjukan bahwa prestasi belajar Bahasa Indonesia materi kemampuan menulis teks recount siswa kelas IX A SMP Negeri 6 Sukoharjo semester I Tahun Pelajaran 2016/2017 masih rendah dan jauh dari yang diharapkan.

Observasi awal menunjukkan bahwa motivasi siswa masih rendah, siswa kurang aktif dalam kegiatan pembelajaran. Kesenjangan antara situasi dan kondisi pembelajaran di kelas IX A dan kondisi ideal pembelajaran Bahasa Indonesia materi kemampuan menulis teks recount menimbulkan beberapa masalah pembelajaran yang harus segera dicari solusinya agar prestasi siswanya semakin meningkat.

Selama ini guru dalam pembelajaran Bahasa Indonesia hanya menggunakan metode konvensional ceramah. Dalam pembelajaran ini guru yang aktif menyampaikan materi pelajaran, sedangkan siswa hanya pasif mendengarkan. Padahal dalam pelajaran Bahasa Indonesia materi kemampuan menulis teks recount, siswa perlu mendapatkan gambaran yang lebih konkrit sehingga lebih mudah memahami materi pelajaran dan dapat meningkat prestasi belajarnya. Untuk mengatasi kesulitan dalam pembelajaran ini, maka peneliti merasa perlu untuk menerapkan metode pembelajaran yang sesuai, metode yang menuntut siswa kelas IX A untuk menemukan konsep pembelajaran secara utuh. Dalam penelitian tindakan kelas ini peneliti akan menerapkan metode estafet writing.

Menurut Sriyono (1992:118), "Metode pemecahan masalah adalah suatu cara pembelajaran dengan menghadapkan siswa kepada sesuatu masalah dipecahkan atau diselesaikan", dengan demikian metode pemecahan masalah mendorong dan memberikan kesempatan seluas-luasnya kepada siswa untuk berinisiatip dan berfikir sistematis dalam menghadapi suatu masalah pada penerapannya. Metode ini cenderung akan lebih banyak menggunakan pendekatan belajar secara kelompok. Dengan ini diharapkan melalui sosialisasi yang dilakukan dalam kelompok siswa 
berlatih bekerja sama, berkoordinasi, saling tukar pikiran, dan mengembangkan komunikasi yang baik kepada guru maupun sesama rekan-rekannya.

\section{KAJIAN TEORI}

\section{Teks Recount}

Teks Recount atau Recount Text adalah salah satu jenis text dalam bahasa Inggris yang menceritakan kembali tentang kejadian-kejadian atau pengalaman-pengalaman di masa lampau. Tujuan dari Recount Text adalah untuk memberikan informasi atau untuk menghibur pembaca sehingga tidak terdapat konflik.

Macam-macam Recount Text antara lain: a) personal recount, yaitu menceritakan tentang pengalaman pribadi penulis. b) factual recount, yaitu laporan peristiwa yang benar-benar terjadi, seperti laporan percobaan ilmu pengetahuan, laporan kepolisian. c) Imaginative, yaitu membuat cerita imaginative lalu menuliskan peristiwa atau kejadian yang telah terjadi.

\section{Metode Estafet Writing}

Metode pembelajaran didefinisikan sebagai cara yang digunakan guru, yang dalam menjalankan fungsinya merupakan alat untuk mencapai tujuan pembelajaran (Uno, 2008:2). Hal tersebut juga sejalan dengan pendapat Slavin (2010:9) bahwa metode pembelajaran sebagai elemen utama dalam pola pengaturan kelas dan digunakan secara ekstensif dalam tiap subjek yang dapat dikonsepkan pada tingkat kelas. Salah satu metode yang dapat digunakan dalam pembelajaran adalah metode estafet writing. Metode estafet writing merupakan salah satu metode active learning atau learning by doing yang bertujuan agar peserta didik mengasosiasikan belajar sebagai sebuah kegiatan yang menyenangkan (Syathariah dalam Mardiansyah, 2013:41-42).

Pada metode estafet writing, peserta didik bekerja secara berkelompok. Setiap kelompok menuangkan perasaannya ke dalam penggalan teks. Hal itu dilakukan secara berantai. Keberhasilan peserta didiksatu akan berpengaruh pada keberhasilan peserta didik yang menjadi pasangannya. Secara bergantian peserta didik menuliskan sebuah penggalan-penggalan bagian teks yang telah ditentukan. Pada akhir pembelajaran akan menghasilkan teks utuh yang ditulis secara berantai oleh para peserta didik. Pembelajaran menulis pantun puisi dengan menggunakan metode estafet writing ini sangat memotivasi peserta didik dalam belajar sehingga berpengaruh terhadap hasil belajarnya. Suasana belajar yang menyenangkan dan tidak membosankan dapat dirasakan oleh peserta didik.

Manusia dilahirkan mempunyai berbagai macam bakat dan keterampilan yang tidak dimiliki oleh makhluk lain. Kemampuan yang dimiliki oleh manusia yang menonjol adalah kemampuan berpikir secara logis. Manusia dapat mengaitkan satu ide dengan ide lainnya melalui pembelajaran. Dengan kemampuan imaginasinya manusia dapat menuangkan ide sesuai dengan apa yang diinginkan. Alwi (2003: 1023) menyatakan kemampuan adalah kecakapan, kesanggupan, kekuatan untuk menyelesaikan tugas. Sama halnya dengan pendapat di atas Depdiknas (2005:707) menyatakan bahwa kemampuan adalah kesanggupan, kecakapan, dan kekuatan.

Dari beberapa pendapat di atas dapat disimpulkan bahwa kemampuan adalah kesanggupan atau kecakapan dalam menghasilkan atau melakukan sesuatu untuk mencapai tujuannnya sesuai dengan kondisi yang diharapkan.

Menulis mempunyai peranan yang sangat penting bagi manusia. Menulis merupakan salah satu sarana komunikasi seperti halnya berbicara. Namun, dalam prakteknya penggunaan bahasa dalam menulis tidaklah sama dengan komunikasi lisan. Hal ini dikarenakan bahasa digunakan secara fungsional yaitu pemakaian bahasa sebagai media interaksi dan transaksi. Dengan demikian, kegiatan menulis menuntut kecakapan dan kemahiran dalam mengatur menggunakan bahasa, bekerja dengan langkah-langkah terorganisir, gagasan secara sistematis serta mengungkapkan secara tersurat. 
Gie (2002:3) menyatakan menulis adalah segenap rangkaian seseorang mengungkapkan buah pikirannya melalui bahasa tulis kepada masyarakat pembaca untuk dipahami. Senada dengan pendapat di atas, Depdiknas (2005:1219) menyatakan menulis adalah melahirkan pikiran atau perasaan dengan tulisan. Sedangkan Sabarti Akhadiyah (1996: 7) mengatakan bahwa kemampuan menulis merupakan kemampuan yang kompleks yang menuntut sejumlah pengetahuan dan keterampilan. Tanpa adanya pengetahuan dari penulis maka ide yang disampaikan kurang bermakna. Kemampuan menulis tidak diperoleh secara tiba-tiba tetapi melalui suatu proses yang panjang, dan memerlukan latihan serta ketekunan untuk mewujudkannya melalui bahasa tulis. Prasyarat yang harus dipenuhinya adalah kemampuan membaca. Bila kemampuan membaca sudah didapat maka kemampuan menulis ini akan mengikutinya.

Berdasarkan pendapat para ahli di atas maka dapat disimpulkan bahwa kemampuan menulis adalah suatu kegiatan yang dilakukan seseorang untuk mengungkapkan pikiran dan perasaan dengan menggali pengetahuan dan pengalaman melalui bahasa tulis.

Keterampilan menulis merupakan salah satu dari empat aspek keterampilan berbahasa. Nursito (2000:5) menjelaskan empat jenjang kemampuan berbahasa yang melekat pada setiap manusia normal adalah menyimak, berbicara, membaca, dan menulis atau mengarang. Secara kronologis, keempatnya tumbuh dalam diri setiap individu. Pada tingkatan paling sederhana, yaitu dalam wujud kemampuan berkomunikasi langsung dengan bahasa lisan, kita memiliki kemampuan menyimak dan berbicara.

Selanjutnya tahapan yang setingkat lebih tinggi adalah membaca, dan yang paling rumit adalah menulis atau mengarang dalam bentuk bahasa tulis. Siswa diharapkan dapat menguasai dan terampil dalam tiap-tiap aspek, namun dalam kenyataannya tidak semua pembelajaran keterampilan berbahasa tersebut mencapai hasil yang memuaskan. Misalnya dalam keterampilan menulis, tidak semua siswa dapat melakukannya dengan baik. Bahkan, keterampilan menulis sering dianggap sebagai keterampilan berbahasa yang paling sulit.

Keterampilan menulis merupakan salah satu aspek berbahasa yang bersifat primer dan kompleks. Menulis memerlukan keahlian dalam menuangkan ide-ide cemerlang dan mengembangkannya menjadi satu karangan yang bagus. Hal ini memerlukan latihan serta pembiasaan. Sumardjo (2004:69) mengemukakan bahwa menulis merupakan suatu proses melahirkan tulisan yang berisi gagasan. Tarigan (1984:21) menjelaskan, bahwa menulis ialah menurunkan atau melukiskan lambang-lambang grafik yang menggambarkan suatu bahasa yang dipahami oleh seseorang, sehingga orang lain dapat membaca lambanglambang grafik tersebut kalau mereka memahami bahasa dan gambaran grafik itu.

Pengertian menulis oleh Ahmadi (1990:28) adalah meletakkan atau mengatur simbol-simbol grafis yang menyatakan pemahaman suatu bahasa sedemikian rupa sehingga orang lain dapat membaca simbol-simbol grafis itu sebagai bagian penyajian satuan-satuan ekspresi bahasa. Menulis juga dapat dipandang sebagai upaya untuk merekam ucapan manusia menjadi bahasa baru, yaitu bahasa tulisan. Bahasa tulisan itu tidak lain adalah suatu jenis notasi bunyi, kesenyapan, infleksi, tekanan nada, isyarat atau gerakan, dan ekspresi muka yang memindahkan arti dalam ucapan atau bicara manusia.

Pengertian menulis oleh Wiyanto (2004:1-2) bahwa menulis mempunyai dua arti. Pertama, menulis berarti mengubah bunyi yang dapat didengar menjadi tanda-tanda yang dapat dilihat. Bunyi-bunyi yang diubah itu bunyi bahasa yang dihasilkan oleh alat ucap manusia. Kedua, menulis itu mempunyai arti mengungkapkan gagasan secara tertulis. Orang yang melakukan kegiatan ini dinamakan penulis dan hasil kegiatannya berupa tulisan. Dapat dikatakan, penulis menuangkan gagasan lewat kegiatan menulis dan pembaca menampung gagasan itu dengan cara membaca. Pengertian menulis oleh Asul Wiyanto dibedakan dengan mengarang. Perbedaannya, menulis menghasilkan tulisan, sedangkan mengarang menghasilkan karangan. 
Tulisan dilandasi fakta, pengalaman, penelitian, pemikiran, atau analisis, sedangkan karangan banyak dipengaruhi oleh imajinasi dan perasaan pengarang. Pendapat Asul Wiyanto mengenai kegiatan menulis merupakan kegitan yang gampang-gampang susah selaras dengan pendapat yang dikemukakan Semi (1990:7-8) yang menyatakan bahwa menulis tidak sulit tetapi tidak pula mudah. Menurutnya, kecakapan menulis dapat menjadi milik semua yang pernah menduduki bangku sekolah. Menulis merupakan suatu keterampilan berbahasa yang produktif, yaitu keterampilan seseorang untuk mengungkapkan atau mengekspresikan ide dan perasaan kepada orang lain melalui bahasa tulis. Gagasan yang dituangkan dalam sebuah tulisan harus lebih tertata dan tertib daripada gagasan yang diungkapkan melalui pembicaraan. Hal ini memiliki tujuan agar pembaca dapat menerima maksud tulisan tersebut dengan mudah.

Menulis merupakan salah satu metode active learning atau learning by doing yang bertujuan agar siswa mengasosiasikan belajar sebagai sebuah kegiatan yang menyenangkan (Syathariah, 2011:41-42). Metode inovatif ini merupakan salah satu metode yang melibatkan siswa belajar dengan cara bersama-sama, tetapi tidak secara kelompok. Kegiatan menulis dengan menggunakan metode pembelajaran ini membuat siswa aktif mengembangkan daya khayalnya, berimajinasi, dan langsung menghasilkan sebuah produk berupa cerita pendek. Produk yang dihasilkan adalah karya bersama, karena cerita pendek yang dihasilkan tersebut dibuat bersama-sama (berantai). Secara bergantian siswa menuliskan paragraf imajinatif dalam buku latihannya (minimal satu paragraf). Pada akhir pembelajaran akan tercipta beberapa paragraf sesuai dengan jumlah siswa di kelas yang ditulis berantai oleh para siswa.

Pembelajaran menulis cerita pendek dengan menggunakan metode menulis berantai ini sangat memotivasi siswa dalam belajar sehingga berpengaruh terhadap hasil belajarnya. Suasana belajar yang menyenangkan dan tidak membosankan dapat dirasakan oleh siswa. Menulis berantai adalah salah satu metode pembelajaran yang bertujuan agar siswa mengasosiasikan belajar sebagai sebuah kegiatan yang menyenangkan. Para siswa diberi kebebasan mengekspresikan imajinasinya melalui tulisan-tulisan yang dihasilkannya seperti cerita pendek. Dalam proses pembelajarannya, kegiatan menulis cerita pendek merupakan proyek bersama yang dilakukan oleh siswa dalam kelompoknya. Pada akhir pembelajaran, akan tercipta sejumlah cerita pendek berantai hasil karya siswa (sejumlah kelompok yang dibentuk dalam pembelajaran). Kegiatan pembelajaran dengan menggunakan metode menulis berantai ini dilakukan sebagai langkah memotivasi siswa dalam mengembangkan imajinasinya untuk menulis cerita pendek yang akan dilaksanakan secara individu dalam kelompok belajarnya.

Pada metode menulis berantai, siswa bekerja di dalam kelompok. Setiap anggota kelompok menuangkan perasaannya ke dalam satu paragraf dengan tema dan judul yang sama. Hal itu dilakukan secara berantai sampai batas waktu yang ditentukan berakhir. Keberhasilan seorang anggota kelompok akan berpengaruh pada keberhasilan kelompoknya.

\section{Langkah Metode Estafet Writing}

Berdasarkan pendapat Masruroh (2014:12), pembelajaran menggunakan metode pembelajaran estafet writing adalah peserta didik bekerja di dalam kelompok. Setiap anggota kelompok menuangkan perasaannya ke dalam satu teks dengan tema dan judul yang sama. Hal itu dilakukan secara berantai. Metode pembelajaran estafet writingmenerapkan langkah-langkah sebagai berikut.

a. Peserta didik bekerja secara berkelompok diminta menentukan sebuah tema yang akan dikembangkan menjadi sebuahkarangan.

b. Setelah peserta didik menyelesaikan penggalan karangan tersebut, mereka diminta untuk menyerahkankertas yang berisi penggalan karangan tersebut kepada guru kemudian guru membagikannya kembali secara acak. 
c. Peserta didik yang menerima kertas yang berisi karangan diminta membaca dan kemudian setiap peserta didik diminta meneruskan (menyambung) karangan tersebut.

d. Setelah kegiatan tulis berantai selesai, setiap siswa diminta mengumpulkan kertas tersebut kepada guru.

Adapun langkah-langkah menulis puisi dengan metode berantai yang dikemukakan Syatariah (2009) adalah sebagai berikut.

a. siswa dibentuk beberapa kelompok yang setiap kelompok terdiri dari 4-6 siswa;

b. siswa diminta menentukan tema bebas yang akan dikembangkan menjadi puisi; langkah selanjutnya, siswa yang pertama mulai menuliskan bait pertama yang isinya sesuai dengan tema dan judul yang sudah ditentukan sebelumnya;

c. pada setiap akhir bait, siswa menuliskan namanya;

d. setelah siswa yang pertama menyelesaikan bait yang pertama, mereka diminta untuk menyerahkan atau memindahkan buku kepada teman disebelah kanannya;

e. siswa yang menerima buku tersebut diharuskan membaca hasil puisi yang sudah dituliskan teman sebelumnya. Kemudian setiap siswa diminta meneruskan atau menyambung puisi tersebut dengan cara menuliskan dibait kedua. Setiap akhir bait siswa menuliskan namanya. Hal ini bertujuan untuk mengetahui pemilik bait yang tidak koheren atau tidak sesuai dengan bait puisi yang sebelumnya;

f. setelah siswa kedua melanjutkan puisi teman sebelahnya, buku diputar kepada teman berikutnya searah jarum jam sampai batas waktu yang ditentukan oleh guru. Setiap siswa wajib membaca puisi dari awal puisi yang akan dilanjutkannya tersebut. Dan begitu seterusnya;

g. langkah selanjutnya, hasil puisi yang dikerjakan secara berantai tersebut dibahas dengan kelompoknya, kemudian menandai kalimat-kalimat yang sumbang atau tidak sesuai dengan kalimat sebelumnya;

h. setelah merevisi puisi tersebut, kemudian anggota kelompok memberi judul yang tepat untuk puisi yang sudah dikerjakan secara berantai; dan

i. salah satu siswa mewakili untuk membacakan hasil puisi dengan suara nyaring dan selanjutnya ditanggapi oleh siswa lain.

\section{Bahasa Indonesia}

1. Pengertian Bahasa Indonesia

Pengertian bahasa telah banyak didefinisikan oleh para ahli menurut pandangan mereka masing-masing. Menurut Santoso, bahasa adalah rangkaian bunyi yang dihasilkan oleh alat ucap manusia secara sadar. Menurut Mackey, bahasa adalah suatu bentuk dan bukan suatu keadaan atau juga suatu sistem dari sekian banyak sistem-sistem, suatu sistem dari suatu tatanan atau suatu tatanan dalam sistem-sistem. Menurut Wibowo, bahasa adalah sistem simbol bunyi yang bermakna dan berartikulasi yang dipakai sebagai alat berkomunikasi oleh sekelompok manusia untuk melahirkan perasaan dan pikiran. Walija mengungkapkan definisi bahasa ialah komunikasi yang paling lengkap dan efektif untuk menyampaikan ide, pesan, maksud, perasaan dan pendapat kepada orang lain. Pengabean berpendapat bahwa bahasa adalah suatu sistem yang mengutarakan dan melaporkan apa yang terjadi pada sistem saraf. Menurut Kerafsm Arapradhipa memberikan pendapat bahwa Bahasa itu Sebagai alat komunikasi antara anggota masyarakat berupa simbol bunyi yang dihasilkan oleh alat ucap manusia atau sistem komunikasi yang mempergunakan simbol-simbol vokal. Menurut Torigan bahasa adalah suatu sistem yang sistematis barangkali untuk sistem generatif atau seperangkat lambang-lambang atau simbolsimbol orbiter.

Dengan demikian maka bahasa adalah suatu sistem dari lambang bunyi arbitrer yang dihasilkan oleh alat ucap manusia dan dipakai oleh masyarakat komunikasi, kerja sama dan 
identifikasi diri. Bahasa lisan merupakan bahasa primer, sedangkan bahasa tulisan adalah bahasa sekunder. Arbitrer yaitu tidak adanya hubungan antara lambang bunyi dengan bendanya. Bahasa Indonesia adalah bahasa yang menjadi wahana komunikasi dan alat ekspresi budaya yang mencerminkan eksistensi bangsa Indonesia. Pengembangan sikap berbahasa yang mencakup kemahiran berbahasa Indonesia dalam wadah pendidikan formal (sekolah) dilaksanakan melalui mata pelajaran atau mata kuliah Bahasa Indonesia.

2. Fungsi Bahasa Indonesia

Bahasa dibentuk oleh kaidah aturan serta pola yang tidak boleh dilanggar agar tidak menyebabkan gangguan pada komunikasi yang terjadi. Kaidah, aturan dan pola-pola yang dibentuk mencakup tata bunyi, tata bentuk dan tata kalimat. Agar komunikasi yang dilakukan berjalan lancar dengan baik, penerima dan pengirim bahasa harus harus menguasai bahasanya.

Bahasa adalah suatu sistem dari lambang bunyi arbitrer yang dihasilkan oleh alat ucap manusia dan dipakai oleh masyarakat komunikasi, kerja sama dan identifikasi diri. Bahasa lisan merupakan bahasa primer, sedangkan bahasa tulisan adalah bahasa sekunder. Arbitrer yaitu tidak adanya hubungan antara lambang bunyi dengan bendanya.

a) Fungsi bahasa ( umum )

Alat ekspresi diri: Bahasa sebagai alat ekspresi diri berarti dengan bahasa manusia dapat menyatukan secara terbuka segala sesuatu yang tersirat di dalam pikiran manusia untuk mengekspresikan diri.

Alat komunikasi: Bahasa merupakan saluran yang memungkinkan untuk bekerja sama dengan sesama manusia. Bahasa sebagai alat komunikasi memungkinkan setiap orang untuk merasa dirinya terikat dengan kelompok sosial tertentu, dan dapat melakukan semua kegiatan kemasyarakatan serta memungkinkan integrasi (pembauran) .

Alat integrasi dan adaptasi sosial: Bahasa sebagai alat integrasi, bahasa memungkinkan setiap penuturannya merasa diri terikat dalam kelompok sosial atau masyarakat yang menggunakan bahasa yang sama, para anggota kelompok itu dapat melakukan kerja sama dan membentuk masyarakat. Bahasa yang sama yang memungkinkan mereka bersatu atau berintegrasi di dalam masyarakat tersebut.

Sebagai alat kontrol sosial: Bahasa dapat digunakan untuk mengatur berbagai aktivitas sosial, merencanakan berbagai kegiatan, dan mengarahkan kedalam suatu tujuan yang di inginkan. Bahasa pula yang dilakukan oleh seseorang. Segala kegiatan atau aktivitas dapat berjalan dengan baik apabila diatur atau dikontrol dengan bahasa.

Menurut Keraf (1984:6) proses sosialisasi dapat dilakukan dengan cara: mempunyai keahlian bicara, membaca dan menulis; bahasa saluran utama dalam memberikan kepercayaan kepada anak-anak yang sedang tumbuh; bahasa menjelaskan dan melukiskan perasaan anak untuk mengidentifikasi dirinya, supaya dapat mengambil tindakan-tindakan yang di perlukan; dan bahasa menawarkan dasar keterlibatan pada si anak tentang masyarakat bahasanya.

b) Fungsi bahasa (khusus)

Fungsi bahasa khusus di sini antara lain: bahasa resmi kenegaraan; bahasa pengantar dalam dunia pendidikan; dan bahasa resmi untuk kepentingan perencanaan pembangunan. Di dalam kedudukannya sebagai bahasa nasional, bahasa Indonesia berfungsi sebagai: lambang kebangsaan; lambang identitas nasional; alat penghubung antarwarga, antardaerah dan antarbudaya; dan alat yang memungkinkan penyatuan berbagai suku bangsa dengan latar belakang sosial budaya dan bahasa yang berbeda-beda ke dalam satu kesatuan kebangsaan yang bulat. Di dalam kedudukannya sebagai bahasa negara, bahasa indonesia berfungsi sebagai: bahasa resmi kenegaraan; bahasa pengantar di dalam dunia pendidikan; alat perhubungan pada tingkat nasional untuk kepentingan perencanaan dan pelaksanaan pembangunan; dan alat pengembangan kebudayaan, ilmu pengetahuan dan teknologi. 
3. Kedudukan Bahasa Indonesia

a) Sebagai Bahasa Nasional

Seperti yang tercantum dalam ikrar ketiga Sumpah Pemuda 1928 yang berbunyiKami putra dan putri Indonesia menjunjung bahasa persatuan, bahasa Indonesia.Ini berarti bahasa Indonesia berkedudukan sebagai bahasa Nasional yang kedudukannya berada diatas bahasabahasa daerah.

b) Sebagai Bahasa Negara

Tercantum dalam Undang-Undang Dasar 1945 (Bab XV Pasal 36) mengenasi kedudukan bahasa Indonesia yang menyatakan bahawa bahasa negara ialah bahasa Indonesia.

Bahasa Indonesia memiliki kedudukan yang sangat penting seperti yang tercantum dalam: Ikrar ketiga Sumpah Pemuda 1928 dengan bunyi, "Kami putra dan putri Indonesia menjunjung bahasa persatuan, bahasa Indonesia. Undang-Undang Dasar RI 1945 Bab XV (Bendera, Bahasa, dan Lambang Negara, serta Lagu Kebangsaan) Pasal 36 menyatakan bahwa "Bahasa Negara ialah Bahasa Indonesia".

Dari Kedua hal tersebut, maka kedudukan bahasa Indonesia sebagai: Bahasa kebangsaan, kedudukannya berada di atas bahasa-bahasa daerah dan Bahasa negara (bahasa resmi Negara Kesatuan Republik Indonesia)

\section{Hakikat Belajar}

Belajar adalah proses perubahan perilaku berkat pengalaman dan latihan. Hamalik (2007: 6-17) mengemukakan bahwa setiap proses belajar selalu berlangsung dalam tiga tahapan sebagai berikut: a) Acquation (tahap perolehan atau penerimaan informasi). Pada tingkatan ini seorang siswa mulai menerima informasi sebagai stimulus dan melakukan respon terhadapnya, sehingga menimbulkan pemahaman dan aktivitas baru. b) Strorage (tahap menyimpan informasi). Pada tingkatan ini seorang siswa akan mengaktifkan fungsi-fungsi memorinya, misalnya ketika ia menjawab pertanyaan atau memecahkan masalah. Proses retrieval pada dasarnya adalah upaya atau peristiwa mental dalam mengungkapkan dan mereduksi kembali apa yang tersimpan dalam materi. c) Retrieval (tahap mendapatkan kembali informasi). Pada tingkatan ini seseorang siswa akan mengaktifkan fungsi-fungsi memorinya, misalnya ketika ia menjawab pertanyaan atau memecahkan masalah. Pross retrieval pada dasarnya adalah upaya atau peristiwa mental dalam mengungkapkan dan memproduksi kembali apa yang tersimpan dalam memori.

Menurut Dimyati dan Mudjiono (2006:156), belajar adalah proses melibatkan manusia secara orang per orang sebagai satu kesatuan organisme sehingga terjadi perubahan pada pengetahuan, keterampilan, dan sikap.

Hakikat belajar adalah perubahan dalam tingkah laku si subyek dalam situasi tertentu berkat pengalamannya yang berulang-ulang, dan perubahan tingkah laku tersebut tidak dapat dijelaskan atas dasar kecenderungan respon bawaan, kematangan atau keadaan temporer dari subjek ( Hilgard dan Gordon, dalam Suyahman, 2006:3).

Dari berbagai pengertian di atas, belajar pada hakekatnya adalah perubahan tingkah laku dari seseorang yang menyangkut pengetahuan, ketrampilan dan sikap. Belajar merupakan peningkatan kemampuan kognitif, afektif dan psikomotorik menjadi lebih baik

5. Prestasi Belajar

Belajar merupakan proses penting bagi perubahan perilaku pada diri seseorang dan mencakup segala sesuatu yang dipikirkan dan dikerjakan. Belajar memegang peranan penting di dalam perkembangan, kebiasaan, sikap, keyakinan, tujuan, kepribadian, dan bahkan persepsi manusia. Di dalam belajar terdapat prinsip-prinsip belajar yang harus diperhatikan, Dalyono (2005: 51-54). 
Salah satu indikator tercapai atau tidaknya suatu proses pembelajaran adalah dengan melihat prestasi belajar yang dicapai oleh siswa. Poerwanto (1986:28), memberikan pengertian prestasi belajar yaitu "hasil yang dicapai oleh seseorang dalam usaha belajar sebagaimana yang dinyatakan dalam raport." Winkel (1996:226) mengemukakan bahwa prestasi belajar merupakan bukti keberhasilan yang telah dicapai oleh seseorang. Maka prestasi belajar merupakan hasil maksimum yang dicapai oleh seseorang setelah melaksanakan usaha-usaha belajar.

Sedangkan menurut Arif Gunarso (1993: 77), mengemukakan bahwa prestasi belajar adalah usaha maksimal yang dicapai oleh seseorang setelah melaksanakan usaha-usaha belajar. S.Nasution (1996: 17), prestasi belajar adalah: "Kesempurnaan yang dicapai seseorang dalam berpikir, merasa dan berbuat. Prestasi belajar dikatakan sempurna apabila memenuhi tiga aspek yakni: kognitif, affektif dan psikomotor, sebaliknya dikatakan prestasi kurang memuaskan jika seseorang belum mampu memenuhi target dalam ketiga criteria tersebut."

Prestasi belajar di bidang pendidikan adalah hasil dari pengukuran terhadap peserta didik yang meliputi faktor kognitif, afektif dan psikomotor setelah mengikuti proses pembelajaran yang diukur dengan menggunakan instrumen tes atau instrumen yang relevan. Jadi prestasi belajar adalah hasil pengukuran dari penilaian usaha belajar yang dinyatakan dalam bentuk simbol, huruf maupun kalimat yang menceritakan hasil yang sudah dicapai oleh setiap anak pada periode tertentu. Prestasi belajar merupakan hasil dari pengukuran terhadap peserta didik yang meliputi faktor kognitif, afektif dan psikomotor setelah mengikuti proses pembelajaran yang diukur dengan menggunakan instrumen tes yang relevan.

Secara psikologis, belajar merupakan suatu proses perubahan tingkah laku sebagai hasil interaksi dengan lingkungan dalam memenuhi kebutuhan hidupnya. Perubahan-perubahan itu akan nyata dari seluruh aspek tingkah lakunya. Belajar adalah suatu proses usaha yang dilakukan seseorang untuk memperoleh suatu perubahan tingkah laku yang baru secara keseluruhan, sebagai hasil pengalamannya sendiri dalam interaksi dengan lingkungannya.

\section{METODE}

Penelitian ini menggunakan bentuk penelitian tindakan kelas yang dilaksanakan dalam 2 (dua) siklus, dilaksanakan di SMP Negeri 6 Sukoharjo dengan subjek penelitian seluruh siswa kelas IX A SMP Negeri 6 Sukoharjo semester I Tahun Pelajaran 2016/2017 yang berjumlah 22 siswa. Metode penelitian menggunakan Penelitian Tindakan Kelas. Pengumpulan data dilakukan melalui observasi, dokumentasi dan tes. Analisis data dilakukan dengan 3 (tiga) tahapan meliputi: reduksi data, penyajian data dan penarikan kesimpulan atau verifikasi.

\section{PEMBAHASAN}

Setelah peneliti melaksanakan tindakan penelitian melalui penerapan metode estafet writing, secara empiris diperoleh data peningkatan prestasi belajar Bahasa Indonesia materi kemampuan menulis teks recount pada siswa kelas IX A SMP Negeri 6 Sukoharjo Kecamatan Sukoharjo, Kabupaten Sukoharjo semester I Tahun Pelajaran 2016/2017 dari kondisi awal, siklus I dan siklus II sebagai berikut. 
Tabel 1. Peningkatan Prestasi Belajar Siswa

\begin{tabular}{|c|c|c|c|}
\hline Uraian & Kondisi awal & Siklus I & Siklus II \\
\hline $\begin{array}{l}\text { Tindakan } \\
\text { Pembelajaran }\end{array}$ & $\begin{array}{l}\text { Belum menerapkan } \\
\text { metode estafet writing }\end{array}$ & $\begin{array}{l}\text { Sudah menerapkan } \\
\text { metode estafet writing }\end{array}$ & $\begin{array}{l}\text { Sudah menerapkan } \\
\text { metode } \text { estafet writing }\end{array}$ \\
\hline Nilai terendah & 60 & 65 & 70 \\
\hline Nilai tertinggi & 80 & 90 & 90 \\
\hline Nilai rata-rata & 70 & 75 & 85 \\
\hline KKM & 75 & 75 & 75 \\
\hline Ketuntasan & 12 siswa $(54,54 \%)$ & 14 siswa $(63,63 \%)$ & 19 siswa $(86,36 \%)$ \\
\hline
\end{tabular}

Melalui penerapan metode estafet writing dapat meningkatkan prestasi belajar Bahasa Indonesia materi kemampuan menulis teks recount.

Pada kondisi awal peneliti belum menerapkan metode estafet writing. Nilai rata-rata siswa kelas IX A adalah 70, masih di bawah nilai KKM yang ditetapkan yaitu 75. Nilai tertinggi siswa 80, nilai terendah 60 dan jumlah siswa kelas IX A yang mencapai nilai KKM hanya 12 siswa (54, 54\%) dari total 22 siswa kelas IX A SMP Negeri 6 Sukoharjo Semester I Tahun Pelajaran 2016/2017.

Pada siklus I guru peneliti sudah menerapkan metode estafet writing dalam pembelajaran Bahasa Indonesia materi kemampuan menulis teks recount. Nilai rata-rata prestasi belajar Bahasa Indonesia materi kemampuan menulis teks recount siswa kelas IX A SMP Negeri 6 Sukoharjo adalah 75, nilai tertinggi 90 dan nilai terendah adalah 65. Sedangkan jumlah siswa yang mencapai nilai KKM sebanyak 14 siswa $(63,63 \%)$ dari total 22 siswa kelas IX A SMP Negeri 6 Sukoharjo.

Pada siklus II, nilai rata-rata prestasi belajar Bahasa Indonesia materi kemampuan menulis teks recount 22 siswa kelas IX A SMP Negeri 6 Sukoharjo adalah 85, nilai tertinggi 90 dan nilai terendah 70. Jumlah siswa yang mencapai nilai KKM sebanyak 19 siswa $(86,36 \%)$ dari total 22 siswa kelas IX A SMP Negeri 6 Sukoharjo.

Jadi, melalui penerapan metode estafet writing dapat meningkatkan prestasi belajar Bahasa Indonesia materi kemampuan menulis teks recount dari kondisi awal nilai rata-rata 70 dengan ketuntasan 54, 54\% ke kondisi akhir pada siklus II nilai rata-rata 85 dengan ketuntasan $86,36 \%$ pada siswa kelas IX A SMP Negeri 6 Sukoharjo semester I Tahun Pelajaran 2016/2017.

Hasil tindakan secara empirik yaitu: melalui penerapan metode estafet writing dapat meningkatkan prestasi belajar Bahasa Indonesia materi kemampuan menulis teks recount dari kondisi awal nilai rata-rata 70 dengan ketuntasan $54,54 \%$ ke kondisi akhir pada siklus II nilai ratarata 85 dengan ketuntasan 86,36\% pada siswa kelas IX A SMP Negeri 6 Sukoharjo semester I Tahun Pelajaran 2016/2017.

\section{SIMPULAN}

Hipotesis menyatakan diduga melalui penerapan metode estafet writing dapat meningkatkan prestasi belajar Bahasa Indonesia materi kemampuan menulis teks recount pada siswa kelas IX A SMP Negeri 6 Sukoharjo semester I Tahun Pelajaran 2016/2017.

Dari data empirik menyatakan melalui penerapan metode estafet writing dapat meningkatkan prestasi belajar Bahasa Indonesia materi kemampuan menulis teks recount dari kondisi awal nilai rata-rata 70 dengan ketuntasan 54, 54\% ke kondisi akhir pada siklus II nilai rata-rata 85 dengan ketuntasan 86, 36\% pada siswa kelas IX A SMP Negeri 6 Sukoharjo semester I Tahun Pelajaran 2016/2017. 
Sehingga dapat disimpulkan bahwa melalui penerapan metode estafet writing dapat meningkatkan prestasi belajar Bahasa Indonesia materi kemampuan menulis teks recount pada siswa kelas IX A SMP Negeri 6 Sukoharjo semester I Tahun Pelajaran 2016/2017.

\section{DAFTAR PUSTAKA}

Ahmadi, Mukhsin. 1990. Strategi Belajar-Mengajar Keterampilan Berbahasa dan Apresiasi Sastra. Malang: YA3

Dalyono. 2005. Prestasi Belajar. Jakarta: Rineka Cipta.

Dimyati dan Mudjiono. 2002. Belajar dan Pembelajaran. Jakarta: Penerbit Rineka Cipta

Djamarah, Syaiful Bahri. 2000. Strategi Belajar Mengajar. Jakarta: PT. Rineka Cipta.

Gunarso, Arif. 1993. Bagaimana Bimbingan dan Penyuluhan Belajar di Sekolah. Surabaya: Usaha Nasional.

Hamalik, Oemar. 2005. Proses Belajar mengajar. Bumi Aksara. Jakarta.

Hamzah, Uno. 2008. Teori Motivasi dan Pengukurannya Analisis di Bidang Pendidikan. Bumi Aksara: Jakarta.

Ilyas, T. 2008. Fungsi dan Pengukuran Prestasi Belajar. Yogyakarta: Pustaka Pelajar.

Keraf, Gorys. 1984. Diksi dan Gaya Bahasa. Jakarta: PT. Gramedia Pustaka

Marpaung, H. (2002). Pengetahuan Kepariwisataan. Bandung: Alfabeta.

Nasution S. 1990. Pengertian Belajar. Bandung: Bumi Aksara.

Poerwanto, Ngalim. 1986. Prinsip-prinsip dan Tehnik Evaluasi Pengajaran. Bandung: Remaja Karya

Pribadi, Benny A. 2009. Model Desain Sistem Pembelajaran. Jakarta: Dian Rakyat

Robert. E Slavin. 2010. Cooperative Learning Teori, Riset dan Praktik. Bandung: Nusa Media

Sagala, Saiful. 2008. Konsep dan Makna Pembelajaran Untuk Membantu Memecahkan Problematika Belajar dan Mengajar. Bandung: Alfabeta

Semi, Atar. 1990. Anatomi Sastra. Padang: Angkasa Raya.

Sriyono. (1992). Teknik Belajar Mengajar Dalam CBSA. Jakarta: Melton Putra.

Suyahman. 2006. Belajar dan Pembelajaran. Sukoharjo: Univet Bantara.

Syatariah, S. 2009. Menulis Berantai Sebagai Metode Inovatif. Pekanbaru: CPI Rumbai.

Syathariah, S. 2011. Estafet Writing (Menulis Berantai). Yogyakarta: LeutikaPrio.

Tho'in, M. (2017). Pembiayaan Pendidikan Melalui Sektor Zakat. Al-Amwal: Jurnal Ekonomi dan Perbankan Syari'ah, 9(2).

Undang-Undang Dasar 1945 (Bab XV Pasal 36)

Wiyanto, Asul. 2004. Terampil Menulis Paragraf. Jakarta: Gramedia Widiasarana Indonesia

Winkel, W.S. 1996. Psikologi Pengajaran. Jakarta: Grasindo. 